e-ISSN: 2721-3013, p-ISSN: 2721-3005

DOI: https://doi.org/10.38035/jafm.v1i2

Received: 11 April 2020, Revised: 22 April 2020, Publish: 6 May 2020 https://creativecommons.org/licenses/by/4.0/

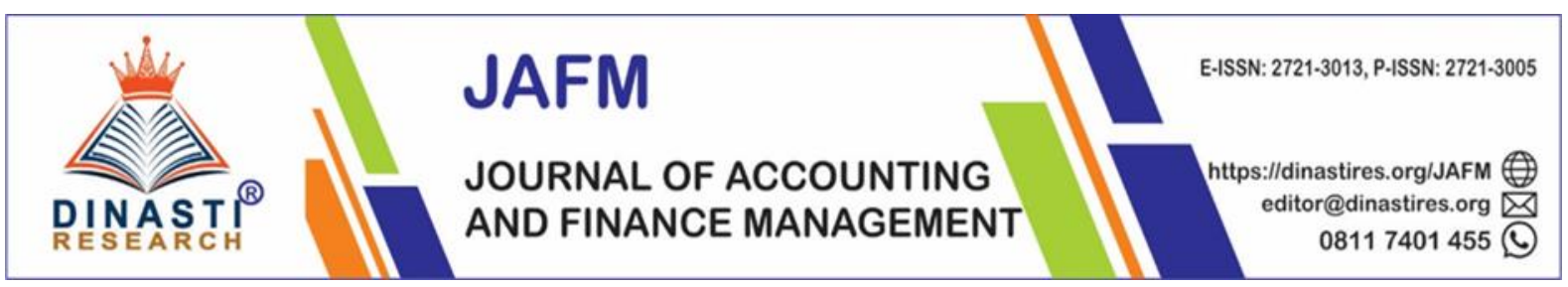

\title{
The Antecedants of Employee Loyalty in Family Business From Millenial Perspectives
}

\author{
Andreas Wijaya ${ }^{1^{*}}$, Brendi Wijaya ${ }^{2}$, Juan Carlos $^{3}$ \\ ${ }^{1)}$ Bunda Mulia University, Jakarta, Indonesia, awijaya@bundamulia.ac.id \\ ${ }^{2)}$ Bunda Mulia University, Jakarta, Indonesia, brendiwijaya@gmail.com \\ ${ }^{3)}$ Bunda Mulia University, Jakarta, Indonesia, juancarlos@ gmail.com \\ *Corresponding Author : Irma Sari Permata ${ }^{1}$
}

\begin{abstract}
According to PWC (2015), almost 80\% family businesses in Indonesia have nonworking family member shareholders. Furthermore, Susenas (2017) projected millenial generation in next five years will increase significantly and reach the peak $34 \%$ of population. To cope these challanges, executives need adoption process to become more professional in business operations while recruiting and retaining qualified employees. This research aim to measure the antesedan of family business for instance; organization culture, empoloyee engagement, ogranizational justice, loyalty. Sample was collected as much 288 selected through purposive sampling method in order to given closed questionarries using likert scale. As a result, organizational culture had impact to employee engagement whereas organizational culture not affected organizational justice, Therefore employee engagement and organizational justice has affected employee loyalty respectivly. Moreover this research reflect new horizons, such as: work autonomy, flexible work arrangements to finding new study of millenial behaviour while HR recuruiting or maintaining employee
\end{abstract}

Keywords: Family Businss, Employee Engagement, Organizational Culture, Organizational Justice, Employee Loyalty

\section{INTRODUCTION}

Indonesian family business plays a key role in economy and society to supporting community employement. According to (Pwc, 2012)80\% family businesses in Indonesia have non-working family member shareholders and $60 \%$ of them have next generation family members. Survey from pwc provide a new insight to transforming into professional management team and transparent an establishment of well structured board, while nepotism in small business identified Business owner have often feared that non-family employees would resent or even, treat unkindly family members brought into the business. The result also provided by (De Kok, Uhlaner, \& Thurik, 2006), in small family business , the owner usually do not use formal work systems because they rely on family members instead of formalization. 
Nonetheless, the past few decades had debates numerous topics, for instance; organizational vision and culture development, human resource practices, inter organizational relationships has predominantly struggled with defining family business and their main characteristics (Mitchell, Morse, \& Sharma, 2003). Several studies had conduct further investigation, such as: (Miller, Le Breton-Miller, Minichilli, Corbetta, \& Pittino, 2014) probing organizational culture to exploring non-family employee involvement, this finding suggest the owner has to create diverse workplace in exchange to continued loyalty, In adittion (Jaskiewicz \& Klein, 2007) find out family business will receive benefit to view the operation with a different lens. Furthermore, findings from (Chrisman, Chua, Pearson, \& Barnett, 2012) conducted another perspective in their studies from non-family employee when their evaluate organizational culture and organizational justice in workplace, the research studies suggest the owner had to bridging the gap between non-family and family treatment in workplace. Lastly, (Tabor, Chrisman, Madison, \& Vardaman, 2018) suggested in future studies, researcher should take another perspective from non family members in family firms to explore the acknowledges the complexities to involvement the employee loyalty.

To answer the recall former studies, this research also considered an issue in labour market to developed research desaign. Nowadays when it becomes in millenial generation, there are an idiosyncratic work attrubutes compared than the older generation.Millennials thrive on challenging work, caring more about creative expression, entrepreneurial thinkers who relish responsibility, demand immediate feedback, expect a frequent sense of accomplishment, and have a high need for organization engagement and support whereas the older generation "baby boomer" valued work hard, tend to be loyal to their employer, concerned about money and recognition prefer job security and desire to be promoted. (Debaro, Yselande, Wei, \& Adly, 2015)“As millennials we need to see that our family business isn't only there to create economic value, but also real social and environmental value, and we need to be able to clearly measure this impact in order to know that we are really creating a positive impact with our activities,". Family leaders have long been interested in how to engage their next generations to sustain the businesses they spent their lives building and to preserve their wealth. Appealing to next-gens' interest in wealth with purpose and social good has been a family strategy in that engagement, with some next gens testing their business acumen in their family's non-core philanthropic efforts.

This paper aims to explore the antecedants of of Employee Loyalty In Family Business From Millenial Perspectives and asnwer the calling from (Tabor et al., 2018) who suggested in future studies, researcher should take another perspective from non family members in family firms to explore the acknowledges the complexities to involvement the employee loyalty. Empirical research specifies in certain aspects of work, including: organizational culture, organizational justice, employee involvement, employee loyalty. This studies involves 288 employee in 35 different companies in Indonesian who worked in SME family business sized.

\section{LITERATURE REVIEW}

This research based on social agency theory (Bierstedt \& Blau, 1965); (Blau, 2017) and developed model from prior studies from (Tabor et al., 2018)) to investigate perspective from non family members to examine employee loyalty. To develop employee loyalty can be influenced by several factors such as organizational culture (Ramos, Man, Mustafa, \& $\mathrm{Ng}$, 2014) employee involvement factors by (Aon Hewitt, 2011); organizational justice by (De Massis, 2012). Indicators for developing employee loyalty (Robbins, 2012) include: a) the desire to survive, b) work optimally, c) accept the value of the organization, d) be loyal to the company. 


\section{Organizational culture}

Organizational culture is (what is important) and trust (ways of working) interact with corporate people, organizational culture, and control systems to produce norms of behavior. (Robbins, 2012)also defines organizational culture as a framework of shared basic conceptions, where it is formed, when organizational members solve internal and comprehensive external adaptation problems. Indicators to measure organizational culture from Robbins and Judge (2012) are: a) Innovation and risk taking. b) detail c) Orientation of results. d) People orientation. e) Team orientation f) competitive

$\mathrm{H}_{1}$ : Organizational culture influences employee involvement $\mathrm{H} 3$ : Organizational culture influences organizational justice

\section{Employee Involvement}

According to research (Aon Hewitt, 2011)) employee involvement is a two-way process of management and employees, where at this stage employees are given the opportunity to participate in their work. Other studies from mercer see that by enforcing employee involvement, employees feel needed to create loyalty. Involvement of employees according to Robbins and Judge (2012): a) work participation, b) participation, c) cooperation.

$\mathrm{H}_{2}$ : Employee involvement influences employee loyalty

\section{Organizational Justice}

Organizational justice is defined perception is the employee's perception of fair and honest treatment in the organization. To measure perceptions of organizational justice, several researchers (Bakhshi, Kumar, \& Rani, 2009)such as dividing the distributive justice sub-dimensions, procedural justice and interactive justice, and overall organizational justice perceptions arise from a combination of these three subdimensions. (Aryee, Budhwar, \& Chen, 2002)) also revealed that providing fair organizational justice can arouse employee loyalty. Indicators of distributive organizational justice measurement include: a) equality, b) eligibility, c) contribution, d) performance.

H4: Organizational justice influences empoyee loyalty

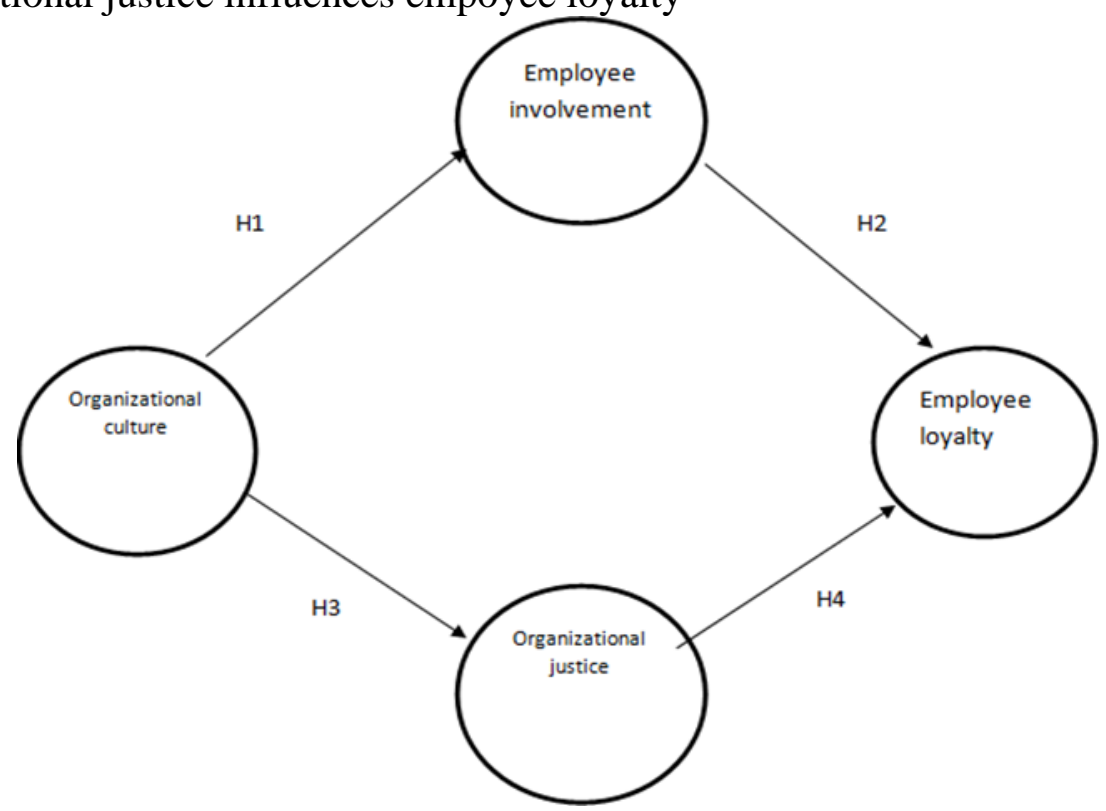

Picture 1. Research Freamework

\section{RESEARCH METHODOLOGY}


This research design contains causal research using purposive sampling in order to given closesd questionarries using 17 instruments with likert scale. Questionarries distributed through purposive sampling method. The criteria for respondents are millennial employees who non-family members and work in family businesses. Data collected was measured using SMARTPLS 3.2.8 to evaluate inner and outer model.

\section{RESULTS AND DISCUSSION}

The following is the description of respondents that can be seen in table below :

Table 1. Respondent Description

\begin{tabular}{|c|c|c|c|}
\hline \multirow[t]{2}{*}{1} & \multicolumn{3}{|l|}{ Gender } \\
\hline & - Male & 122 & $42,36 \%$ \\
\hline & - $\quad$ Female & 166 & $57,64 \%$ \\
\hline & Respondent Amount & 288 & $100 \%$ \\
\hline \multirow[t]{6}{*}{2} & Age & & \\
\hline & - $21-25$ & 119 & $41.32 \%$ \\
\hline & - 26-30 & 94 & $32.64 \%$ \\
\hline & - $26-30$ & 75 & $26.04 \%$ \\
\hline & $\bullet \quad 31-37$ & & \\
\hline & Respondent Amount & 288 & $100 \%$ \\
\hline \multirow[t]{5}{*}{3} & Working Experience & & \\
\hline & - 1-3 years & 127 & $44.10 \%$ \\
\hline & - 3-5 years & 103 & $35.76 \%$ \\
\hline & - $>5$ years & 58 & $20.14 \%$ \\
\hline & Respondent Amount & 288 & $100 \%$ \\
\hline
\end{tabular}

Based on the data collected by 288 respondents, it can be seen that the most gender is female, with a range of 21-25 years old, and length of work 1-3 years.

\section{Data Analysis}

Data was measured using SMARTPLS 3.2.8 software to examine outer model test including validity and reliability test, and inner model used to involve the coefficient of determination test and significance of path coefficients test.

\section{Outer model:}

The outer model provides examining individual indicator reliabilities to reach construct's composite of measures as well as the measures convergent and discriminant validity (Wijaya, 2019).

\section{Validity Test}

Validity was measured by AVE (Average Variance Extracted) and reliability was measured by Cronbach's alpha and composite reliability.

Table 2. Construct Realibility and Validity

\begin{tabular}{ccc}
\hline & AVE & Communality \\
\hline Organization Culture & 0,852311 & 0,827235 \\
\hline Employee Involvement & 0,640493 & 0,682391 \\
\hline Organizational Justice & 0,784102 & 0,732523 \\
\hline Employee loyalty & 0,721094 & 0,782358 \\
\hline
\end{tabular}


The loading factor is 0.5 for each variable in AVE and communality (Wijaya, 2019) From these data it can be seen that each variable is already valid because the AVE and Comunalty values are above 0.5 .

\section{Discriminant Validity}

\begin{tabular}{|c|c|c|c|c|}
\hline & Organizational cu. & Organizational ju & Employee involv... & Employee loyal... \\
\hline OC1 & 0,745 & 0,240 & 0,251 & 0,322 \\
\hline OC2 & 0,662 & 0,279 & 0,279 & 0,242 \\
\hline $\mathrm{OC} 3$ & 0,736 & 0,391 & 0,357 & 0,332 \\
\hline $\mathrm{OC4}$ & 0,605 & 0,278 & 0,215 & 0,212 \\
\hline OC5 & 0,935 & 0,439 & 0,385 & 0,550 \\
\hline OC6 & 0,859 & 0,296 & 0,301 & 0,521 \\
\hline OJ1 & 0,265 & 0,308 & 0,777 & 0,189 \\
\hline OJ2 & 0,356 & 0,402 & 0,388 & 0,309 \\
\hline OJ3 & 0,216 & 0,579 & 0,289 & 0,233 \\
\hline El1 & 0,221 & 0,490 & 0,504 & 0,312 \\
\hline EI2 & 0,340 & 0,436 & 0,617 & 0,440 \\
\hline El3 & 0,315 & 0,241 & 0,515 & 0,296 \\
\hline El4 & 0,214 & 0,275 & 0,633 & 0,234 \\
\hline EL1 & 0,433 & 0,490 & 0,504 & 0,732 \\
\hline EL2 & 0,243 & 0,323 & 0,237 & 0,630 \\
\hline EL3 & 0,385 & 0,231 & 0,455 & 0,532 \\
\hline EL4 & 0,321 & 0,362 & 0,333 & 0,612 \\
\hline
\end{tabular}

Picture 2. Discriminant validity

Looking at the data, it can be interprated as valid criteria when each indicator of the original variable is greater than the other variables (Wijaya, 2019).

\section{Reliability Test}

Table 3. Reliability Test

\begin{tabular}{ccc}
\hline & Cronbach's Alpha & Composite Reliability \\
\hline Organization Culture & 0,769232 & 0,783192 \\
\hline Employee Involvement & 0,784635 & 0,771295 \\
\hline Organizational Justice & 0,728723 & 0,761299 \\
\hline Employee Loyalty & 0,7824812 & 0,788564 \\
\hline
\end{tabular}

From these data it can be seen that the variables are reliable because the value of Cronbach's Alpha and composite reliability have values> 0.70 (Wijaya, 2019).

\section{Path Coefficient Test}

Table 4. T-statistic

\begin{tabular}{ccc}
\hline & T Statistics & P Values \\
\hline Organization Culture -> Employee Involvement & 1,289534 & 0,245 \\
\hline Employee Involvement -> Employee Loyalty & 4,83723 & 0,000 \\
\hline Organization Culture -> Organizational Justice & 3,26245 & 0,000 \\
\hline Organizational Justice -> Employee Loyalty & 3,796336 & 0,000 \\
\hline
\end{tabular}


As described in table above, $\mathrm{H} 1$ is rejected, this indicates that organizational culture can't influence employee involvement, this findings has contrary with prior studies from (Ramos et al., 2014). Inspite of the model contains same variable, sample was taken from different perpective. When millennial work they need a social aspects (Hershatter \& Epstein, 2010) thus this need to investigate in-depth to see clearly the complexity how encourage them to get involved in the company. $\mathrm{H} 2$ is accepted, this finding shows that employee involvement has influence on employee loyalty, the result has a selfsame from (Aon Hewitt, 2011), when employee had been involved they will feel comfort and being loyal. H3 is accepted, thus that organizational culture has influence on organizational justice, mentioned had similiarity from (Bakhshi et al., 2009) organizational justice was derive from organizational culture. $\mathrm{H} 4$ is accepted, means organizational justice has influence on employee loyalty., clarify had identical result from (De Massis, 2012), employees respond stronger to organizational justice while recognizing loyalty.

\section{CONCLUSION}

Based on the results of the study, lead us to the following conclusions: organizational justice has influence employee loyalty, this finding augmented (Pan, Chen, Hao, \& $\mathrm{Bi}$, 2018)): family firms with positve nonfamily perceptions of justice, increased loyalty and decreased turnover. Another variable, employee involvement had to be maintained with innovation of work, reearch from (Barnett \& Kellermanns, 2006) family firms with high family involvement can decrease nonfamily involvement. Furthermore, Organizational culture has influence on organizational justice, this finding also explained by (De Massis, 2012) explore in social exchange theory: family firms with weak visions and restricted exchange will have negative justice climates, vice versa firms with strong and clear visions will have positive justice climates

Organizational culture does not significantly influence employee involvement, from millennial employees perspective they don't feel encouraged to get involved in the company. To clear this finding need a more understanding, (Debaro et al., 2015) explore millennial need a social aspects to invovle them, survey from ( $\mathrm{Ng}$, Schweitzer, \& Lyons, 2010) millennials need flexibilty to encourage them. From this findings this can be another new horizon to explore what kind organizational culture such as: work autonomy, flexible work arrangement whereas this paper has a limitations which doesn't include the spesific family business organization. This findings suggest to investigate more clearly in research subject to give another insight, Do they need to change their culture or hiring new employee in similar attitiude,Consideration from another researcher (Tabor et al., 2018) Confirmed to hiring non family members are the requirement to further growth expansion, because of limited in size and capabilites in family; On the other hand, (Dyer, 1989)research indicates that family firms do not formalize because of the potential costs, therefore may be due to potential conflict of interest and a lack of cultural fit between the manager and the family. The formalization will being disruptive while providing better career opportunities and compensation.

\section{REFERENCES}

Aon Hewitt. (2011). The Multiplier Effect: Insights into How Senior Leaders Drive Employee Engagement Higher. Aon Hewitt.

Aryee, S., Budhwar, P. S., \& Chen, Z. X. (2002). Trust as a mediator of the relationship between organizational justice and work outcomes: Test of a social exchange model. Journal of Organizational Behavior. https://doi.org/10.1002/job.138 
Bakhshi, A., Kumar, K., \& Rani, E. (2009). Organizational justice perceptions as predictor of job satisfaction and organization commitment. International Journal of Business and Management. https://doi.org/10.5539/ijbm.v4n9p145

Barnett, T., \& Kellermanns, F. W. (2006). Are we family and are we treated as family? Nonfamily employees' perceptions of justice in the family firm. Entrepreneurship: Theory and Practice. https://doi.org/10.1111/j.1540-6520.2006.00155.x

Bierstedt, R., \& Blau, P. M. (1965). Exchange and Power in Social Life. American Sociological Review. https://doi.org/10.2307/2091154

Blau, P. M. (2017). Exchange and power in social life. Exchange and Power in Social Life. https://doi.org/10.4324/9780203792643

Chrisman, J. J., Chua, J. H., Pearson, A. W., \& Barnett, T. (2012). Family Involvement, Family Influence, and Family-Centered Non-Economic Goals in Small Firms. Entrepreneurship: Theory and Practice. https://doi.org/10.1111/j.1540$\underline{6520.2010 .00407 . x}$

De Kok, J. M. P., Uhlaner, L. M., \& Thurik, A. R. (2006). Professional HRM practices in family owned-managed enterprises. Journal of Small Business Management. https://doi.org/10.1111/j.1540-627X.2006.00181.X

De Massis, A. (2012). Family Involvement and Procedural Justice Climate Among Nonfamily Managers: The Effects of Affect, Social Identities, Trust, and Risk of NonReciprocity. Entrepreneurship: Theory and Practice. https://doi.org/10.1111/j.1540$\underline{6520.2012 .00547 . \mathrm{X}}$

Debaro, H., Yselande, P., Wei, D., \& Adly, N. (2015). Millennials in the Workplace: Positioning Companies for Future Success. 14th Annual South Florida Education Research Conference.

Dyer, W. G. (1989). Integrating Professional Management into a Family Owned Business. Family Business Review. https://doi.org/10.1111/j.1741-6248.1989.00221.x

Hershatter, A., \& Epstein, M. (2010). Millennials and the world of work: An organization and management perspective. Journal of Business and Psychology. https://doi.org/10.1007/s10869-010-9160-y

Jaskiewicz, P., \& Klein, S. (2007). The impact of goal alignment on board composition and board size in family businesses. Journal of Business Research. https://doi.org/10.1016/j.jbusres.2006.12.015

Miller, D., Le Breton-Miller, I., Minichilli, A., Corbetta, G., \& Pittino, D. (2014). When do Non-Family CEOs Outperform in Family Firms? Agency and Behavioural Agency Perspectives. Journal of Management Studies. https://doi.org/10.1111/joms.12076

Mitchell, R. K., Morse, E. A., \& Sharma, P. (2003). The transacting cognitions of nonfamily employees in the family businesses setting. Journal of Business Venturing. https://doi.org/10.1016/S0883-9026(03)00059-4

Ng, E. S. W., Schweitzer, L., \& Lyons, S. T. (2010). New generation, great expectations: A field study of the millennial generation. Journal of Business and Psychology. https://doi.org/10.1007/s10869-010-9159-4

Pan, X., Chen, M., Hao, Z., \& Bi, W. (2018). The effects of organizational justice on positive organizational behavior: Evidence from a large-sample survey and a situational experiment. Frontiers in Psychology. https://doi.org/10.3389/fpsyg.2017.02315

Pwc. (2012). Family firm: A resilient model for the 21st century. Pwc - Family Business Survey 2012.

Ramos, H. M., Man, T. W. Y., Mustafa, M., \& Ng, Z. Z. (2014). Psychological ownership in small family firms: Family and non-family employees' work attitudes and behaviours. Journal of Family Business Strategy. https://doi.org/10.1016/j.jfbs.2014.04.001 
Robbins, S. (2012). Management. Angewandte Chemie International Edition. https://doi.org/10.1080/10587259208028779

Tabor, W., Chrisman, J. J., Madison, K., \& Vardaman, J. M. (2018). Nonfamily Members in Family Firms: A Review and Future Research Agenda. Family Business Review. https://doi.org/10.1177/0894486517734683

Wijaya, A. (2019). Metode Penelitian Menggunakan Smart PLS 03 (1st ed.). Jakarta: Innosains. 